$10-2020$

\title{
Reflections By Hillary Rodham Clinton: Kate Millett Memorial Service
}

Hillary Rodham Clinton

\section{Recommended Citation}

Rodham Clinton, Hillary (2020) "Reflections By Hillary Rodham Clinton: Kate Millett Memorial Service," Dignity: A Journal of Analysis of Exploitation and Violence: Vol. 5: Iss. 2, Article 17. https://doi.org/23860/ dignity.2020.05.02.17

This Kate Millett Memorial Issue is brought to you for free and open access by DigitalCommons@URI. It has been accepted for inclusion in Dignity: A Journal of Analysis of Exploitation and Violence by an authorized editor of DigitalCommons@URI. For more information, please contact digitalcommons-group@uri.edu. 


\section{Reflections By Hillary Rodham Clinton: Kate Millett Memorial Service}

Creative Commons License

(c) (i)@(ङ)

This work is licensed under a Creative Commons Attribution-Noncommercial-No Derivative Works 4.0 License. 


\section{DIGNITY}

Volume 5, Issue 2, Article 17, 2020
A JOURNAL ON

SEXUAL EXPLOITATION

AND VIOLENCE

https://doi.org/23860/dignity.2020.05.02.17

\section{REFLECTIONS BY HILLARY RODHAM CLINTON: KATE MILLETT MEMORIAL SERVICE Hillary Rodham Clinton \\ (https://www.hillaryclinton.com/)}

\section{HILLARY RODHAM CLINTON}

November 9,2017

Dear Friends:

It is with a heavy heart that I send greetings to all those gathered this afternoon to honor and celebrate the life of Kate Millett.

Kate was an extraordinary woman whose fierce brilliance and pioneering work shaped the feminist movement, inspiring and informing decades of conversation about gender, sexuality, the family, and society. Hers was a unique and original voice, and I will always be grateful for her contributionsto the women's movement, both here and around world.

As you come together today to shed a tear, share a laugh, and remember and celebrate Kate'slife and work, please know that my warmest wishes and heartfelt condolences are with you, her wife, Sophie, and all those whose lives she touched.

With warmregards,Iam

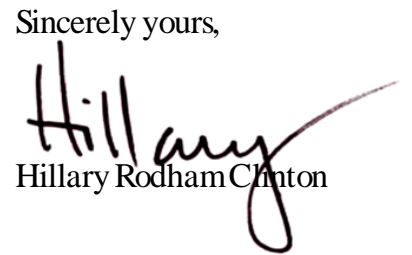




\section{RECOMMENDED CITATION}

Clinton, Hillary Rodham. (2020). Reflections by Hillary Rodham Clinton: Kate Millett memorial service. Dignity: A Journal of Sexual Exploitation and Violence. Vol. 5, Issue 2, Article 17. https://doi.org/23860/dignity.2020.05.02.17 Available at http://digitalcommons.uri.edu/dignity/vol5/iss2/17. 